UDC $\quad 621.791 .79: 621.785 .375: 539.42: 669.14 .018 .292$

技術報告

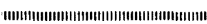

$\mathrm{SM} 41 \mathrm{~B}$ 厚鋼板・エレクトロスラグ溶接部の破壊勒性に およぼす後熱処理の影響*

松 本 浩 造**.高 井耕 一**

\title{
Effect of Post-weld Heat Treatment on the Fracture Mechanics Behaviour for Electroslag Welding Joints of SM41B Heavy Thickness Plate
}

Kozo Matsumoto and Kohichi TAKaI

\section{Synopsis:}

The effect of post welding heat treatments on the notch toughness and fracture mechanics behaviour of $110 \mathrm{~mm}$ thick JIS SM41B steel electroslag welding joints has been investigated. The results obtained are summarized as follows:

1. Notch toughness of welded joints normalized became excellent in heat-affected zone, but in weld metal it became lower. In case of stress relief annealed condition weld metal showed best notch toughness. This reason is considered to the variation of microstructure.

2. Fracture toughness values $\left(K_{\mathrm{IC}}\right)$ of welded joints showed an excellent trend in heat-affected zone with both normalized and stress relief annealed conditions.

3. Fatigue crack growth property of welded joints under stress relief annealed condition was more excellent than those of normalized joints and base metal.

4. There was good correlation between $K_{1 \mathrm{C}}$ and Charpy transition temperature for both base metal and its welded joints.

5. Dynamic fracture toughness values $\left(K_{\mathrm{Id}}\right)$ estimated by instrumented Charpy tests can be correlated with static fracture toughness values $\left(K_{\mathrm{IC}}\right)$ by rate parameter theory.

\section{1. 緒言}

近年，鋼構造物の大形化に伴い銅板の極厚化が進めら れ，かつ大形構造物では製造工程の合理化を目的として 溶接構造が大幅に採用されてきているが，とくに溶接継 手によつて拘束された厚鋼板の板厚方向に応力が頁荷さ れる場合には，ラメラテアの発生に留意する必要があ る.

ラメラテアについては発生機棒ならびにその防止策1 などに関してかなりの検討がなされてきているが，店鋼 板そのものの性状と板厚方向の機械的性質および破壊靶 性の変化を把握することも機器安全性を高めるためには 重要なことである.

一方, 厚鋼板の溶接は自動化·高能染化の点からエレ
クトロスラグ溶接法の適用が増大している.しかし本溶 接方法は大入熱溶接であるため継汗の鞁性に問題がある とされ，溶接後の焼準を必要としてきた.

このエレクトロスラグ溶接継手の靶性劣化に関しては その劣化機構の解明さらには母材の添加元素による影 留2)などについて検討が進められてきている。しかしな がら溶接継手部の機械的性質に及ぼす溶接条件および後 熱処理の影響などについてはまだ定量的に明らかにされ ていない上思われる。

著者らは以上の観点にたつて発電用水東棈造部材に使 用される板厚 $110 \mathrm{~mm}$ の溶接構造用压延鋼板 (SM41B) の板厚方向における切欠䩒性ならびに破壤靶性挙動など

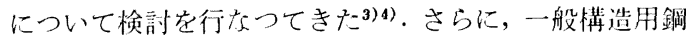
板のエレクトロスラグ溶接部の機械的性質に及ぼす後熱

* 昭和 52 年 11 月 9 日受付 (Received Nov. 9, 1977)

** 富士電機製造(株) 中央研究所 (Central Research Laboratory, Fuji Electric Co., Ltd., 2-2-1 Nagasaka Yokosuka 240-01) 
処理の影镜を調査し，かつ破壤力学的アプローチによつ て浴接継手部の安全性を確認する一連の实駼を实施して きている56).

本淪交では水車部材に使用される板厚 $110 \mathrm{~mm} の$ SM41B 厚鋼㤆エレタトロスラグ溶接部の引張特性・Vシ ヤルピー衝紧特情占よび破填靶性值と疲れき裂進展速度 などに及ぼす溶㢺条件（入熱量）および後熱処理の影留

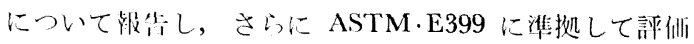

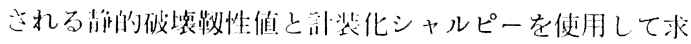
めた動的破溒䩲性值との相同などについても考察在行な う。な，著者らの实施しているこの一連の实験は，一

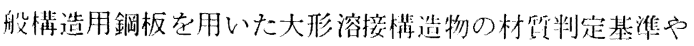
强度設計基準を，破壊力学の諸概念にもとづき，より定 卢的にあたえるここを意威しているものである。

\section{2. 供試材と実験方法}

\section{$2 \cdot 1$ 供試材}

仯試材は板厚 $110 \mathrm{~mm}$ の溶接構造用压延鋼板 (SM41B) であり, その化学成分を Table 1 に示す. 本供試材は 耐ラメラテア銅板として，特别な溶製工程によつて脱硫 在阙つたものであり，压正加工したのち焼ならし処理 $\left(910^{\circ} \mathrm{C} \cdot \mathrm{AC}\right)$ を行なつてある.

\section{2 溶接条件}

溶接は多電㥛消耟ズル式エレクトロスラグ溶接法に よつて Table 2 に示与条件で行なつた，本条件は溶接 の際の入熱量を大幅に変化させることを目的として設定 したものであるが，実測した溶接速度をもとに算出した 入熱量（電蚱×電流/溶接速度）はあまり差異がなかつ †.

溶接後の熱処理は烍ならし炸もどし処理（以下NTを 称する）と応力除去焼なまし処理（以下 $\mathrm{SR}$ と称する） の 2 条件とし次の工程で実施した.

(1) 烍ならし輓もどし $(\mathrm{NT}): 300^{\circ} \mathrm{C} \stackrel{50^{\circ} \mathrm{C} / \mathrm{h}}{\longrightarrow} 910^{\circ}$

Table 1. Chemical composition of SM41B steel plate tested (wt \%).

\begin{tabular}{c|c|c|c|c}
\hline $\mathrm{C}$ & $\mathrm{Si}$ & $\mathrm{Mn}$ & $\mathrm{P}$ & $\mathrm{S}$ \\
\hline 0.16 & 0.14 & 0.75 & 0.011 & 0.003 \\
\hline
\end{tabular}

Table 2. Electroslag welding conditions.

\begin{tabular}{|c|c|c|c|c|c|}
\hline \multicolumn{2}{|c|}{ Electrode } & \multirow{2}{*}{$\begin{array}{c}\text { Current } \\
\text { (A) }\end{array}$} & \multirow{2}{*}{$\begin{array}{c}\text { Voltage } \\
\text { (V) }\end{array}$} & \multirow{2}{*}{$\begin{array}{l}\text { Velocity } \\
(\mathrm{cm} / \mathrm{min})\end{array}$} & \multirow{2}{*}{$\begin{array}{l}\text { Heat- } \\
\text { imput } \\
(\mathrm{kJ} / \mathrm{cm})\end{array}$} \\
\hline$(\mathrm{mm} \dot{\phi})$ & Number & & & & \\
\hline $\begin{array}{l}2.4 \\
2.4\end{array}$ & $\begin{array}{l}2 \\
3\end{array}$ & $\begin{array}{r}800 \\
1000\end{array}$ & $\begin{array}{l}45 \\
45\end{array}$ & $\begin{array}{l}13.8 \\
16.0\end{array}$ & $\begin{array}{l}2600 \\
2800\end{array}$ \\
\hline
\end{tabular}

$\mathrm{C} \times 2 \mathrm{~h}$ AC $300^{\circ} \mathrm{C} \stackrel{50^{\circ} \mathrm{C} / \mathrm{h}}{\longrightarrow} 625^{\circ} \mathrm{C} \times 4 \mathrm{~h} \stackrel{50^{\circ} \mathrm{C} / \mathrm{h}}{\longrightarrow}$ $300^{\circ} \mathrm{C}$ AC

(2) 応力除去烍ななし (SR) : $300^{\circ} \mathrm{C} \stackrel{50^{\circ} \mathrm{C} / \mathrm{h}}{\longrightarrow} 625^{\circ}$ $\mathrm{C} \times 4 \mathrm{~h} \stackrel{50^{\circ} \mathrm{C} / \mathrm{h}}{\longrightarrow} 300^{\circ} \mathrm{C} \quad \mathrm{AC}$

\section{$2 \cdot 3$ 試片採取要領}

母吽（以下 BM と略㐾）の引限とVシャルピー試片 は，試片法方问が压延方向と平行となるように板厚中 失部 $(1 / 2 \mathrm{t})$ から採取した。また破填靶性と疲れき裂進 展試片は，き裂の進行が板愿中部になるように切欠を 加工したものである.

溶接部の各種試験片は熱影暗部 (HAZ と略記)，溶接 金属（WM と略記）および融合㑽界 (Bond と略記) から 採取したが，この際はとくに採取位置の影響は考慮しな かつた。 また溶接部における破壊靶性と疲れき裂進展試 験は入熱量が $2600 \mathrm{~kJ} / \mathrm{cm}$ のみにつて実施し, ボンド についてはVシャルピー術整試験のみを行なつた。

\section{4 引張試験}

引張試験片は直径 $6 \mathrm{~mm} \phi$, 平行部長さ $30 \mathrm{~mm}$ のもの を用いた。試䮖は $10 \mathrm{t}$ 容量のインストロン試験機でク

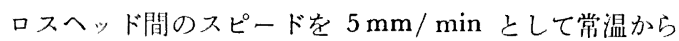
- $120^{\circ} \mathrm{G}$ の温度範囲で実施した。

\subsection{Vシャルピー衝撃試験}

JIS·Z2202の 4 号試験片 (2 mmVノッチ)を採用し, 試駗は $30 \mathrm{~kg} \cdot \mathrm{m}$ 容量のシャルピー覀梁試験機で行なつ t.

\section{6 破壊靶性試験}

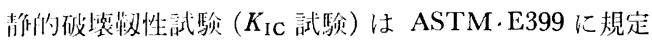
さ机ている板厚 25 と $50 \mathrm{~mm}$ のコンパクトテンション 形試片 (CT 1 と CT 2) および板厚 $75 \mathrm{~mm}$ の三点曲げ 陚片（3 BT）で实施した。試片に対する子疲学き裂は電

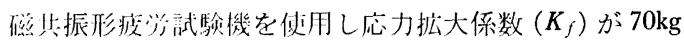
$/ \mathrm{mm}^{3 / 2}$ 前後, 侕重繰返し数は約 $5 \times 10^{5}$ 回の条件で尊 入した。試験は $30 \mathrm{t}$ 万能試駼機を使用し，ASTM·E399 の方泛に优つて行なつた。

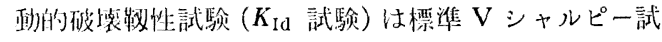
片の $\mathrm{V}$ ノッチ下約 $1 \mathrm{~mm}$ を目標に疲れき裂を導入し， 側面にプレスノッチを压入した試駼片を用いた・疲れき 裂縲入洔の $K_{f}$ は $55 \mathrm{~kg} / \mathrm{mm}^{3 / 2}$ 前後, 荷重繰返し数は 約 $1 \times 10^{4}$ 回であつた. 予疲労き裂導入後, 容量 $30 \mathrm{~kg}$. $\mathrm{m}$ の計装化シャルピー試駼機によつて実施し，このとき えられる荷重一㭙間曲線より脆性破壊荷雨 $\left(P_{f}\right)$ を求め, ASTM·E399 の諳算式に倠つて $K_{\text {Id }}$ を算出した。 

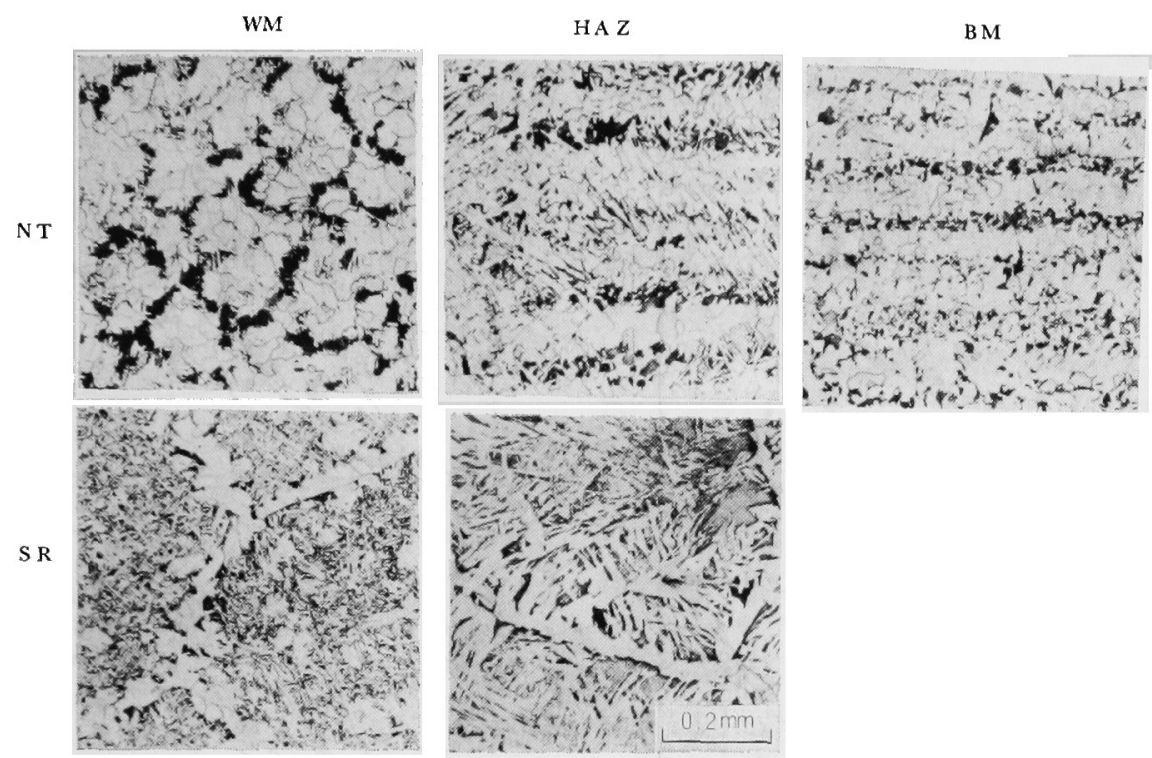

Photo. 1. Microstructure of SM41B welded joints.

\section{7 疲れき裂進展試験}

試験片は板厚が $5 \mathrm{~mm}$ のコンパクトテンション形試 片を用い,大気中とモデル河川水条件下 $(\mathrm{Cl}-=100 \mathrm{ppm}$, 以下水中と称する）で行なつた，き裂長さの測定は，大 気中は試片表面に貼付したクラックゲージの抵抗变化 で，水中は工具顕微鏡で実施した。

試験は電磁共振形疲労試験機 $(4500 \mathrm{cpm})$ とインスト ロン試験機 $(15 \mathrm{cpm})$ を用いて荷重制御・片振引張条件下 で行なつた。

\section{8 組織と破面の観察}

母材と溶接部の組織はナイタルで腐食し, 光学顕微鏡 で観察した、また，疲れき裂進展試片の破面芝走查形々 透過形電子顕微鏡によつて観察した。

\section{3. 実験結果と検討}

\section{1 母材と溶接部の組織変化}

母材と入熱量が $2600 \mathrm{~kJ} / \mathrm{cm}$ の溶接部のミク口組織 をPhoto. 1 に示寸. 母材の組織はつェライトとパーラ イトよりなつている. SR 処理の HAZ は昍オーステナ イト粒界に初析フェライトが存在し，粒内には方向性を もつたフェライトとパーライトが観察される。WM は才 ーステナイト粒界から発生したウィッドマンステッテン ・フェライトと上部ベイナイトの混合組織を呈している.

NT 処理した HAZ は母材とほぼ同様であるが, 一部 のフェライトとパーライトは方向性をもつた微細な組織 になつている。
WM はパーライトの網状組織が発垟し、フェライト も粗大化しているのが認められる.

入熱量が $2800 \mathrm{~kJ} / \mathrm{cm}$ のミクロ組織は Photo. 1 に示 したものとほぼ同梯であるが，WM では粒内のウィド マンステッテン・ェライトが多くなり，HAZ の組織は 若干粗大化しているのが観察された。

\section{$3 \cdot 2$ 引張特性}

常温における母材と溶接部 (入熱量 $=2600 \mathrm{~kJ} / \mathrm{cm}$ ) の 引張試験結果を Table 3 に示す. 母材之 NT 処理溶接 部の引張特性はほぼ同等である. SR 処理溶接部の降伏 点と引張強さは母材拉よび NT 処理のものより高くな つているが，絞りは低下している。このように NT 处 理すると強度は若干低下寸るが，延性は向上すること老 示している.

また乎材扮よび溶接部の降伙点々引張強さは試駼温度 低下に伴なつて漸增傾向となる．そして降伏応力の試験 温度依存性は母材より溶接部の方が大きくなつていた。

Table 3. Tensile test results of SM4lB electroslag welded joints. (Heat-imput $=2600 \mathrm{~kJ} / \mathrm{cm}$ )

\begin{tabular}{c|c|c|c|c|c}
\hline $\begin{array}{c}\text { Heat } \\
\text { treatment }\end{array}$ & Position & $\begin{array}{c}\text { YP } \\
\left(\mathrm{kg} / \mathrm{mm}^{2}\right)\end{array}$ & $\begin{array}{c}\text { TS } \\
\left(\mathrm{kg} / \mathrm{mm}^{2}\right)\end{array}$ & $\begin{array}{c}\mathrm{EL} \\
(\%)\end{array}$ & $\begin{array}{c}\text { RA } \\
(\%)\end{array}$ \\
\hline \multirow{3}{*}{ NT } & BM & 25.6 & 43.3 & 46.2 & 74.1 \\
& HAZ & 25.1 & 43.3 & 34.3 & 72.5 \\
& WM & 25.5 & 42.7 & 35.2 & 73.3 \\
\hline \multirow{2}{*}{ SR } & HAZ & 26.9 & 46.1 & 38.3 & 65.4 \\
& WM & 27.8 & 47.0 & 39.6 & 67.4 \\
\hline
\end{tabular}




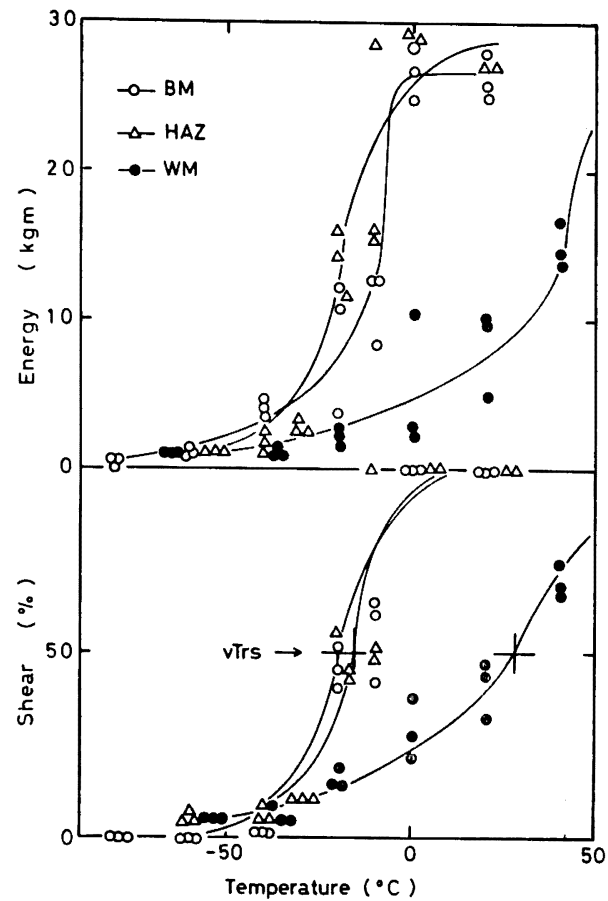

Fig. 1. Charpy transition behaviour of SM41B welded joint under normalized condition.

溶接部では $\mathrm{SR} よ り \mathrm{NT}$ 処理のものが，かつ $\mathrm{HAZ}$ が もつとも大きい試験温度依存性を示すことが認められ た.

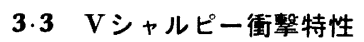

入熱量が $2600 \mathrm{~kJ} / \mathrm{cm}$ の場合の NR と SR 処理溶接 部の破面と吸収エネルギーの暧移曲線を Fig. 1 と 2 に 示寸. NT 処理の HAZ は母材とほぼ同様な傾向である が， $50 \%$ 破面㖶移温度 $\left({ }_{V} T_{r s}\right)$ は $-16^{\circ} \mathrm{C}$ となり母材よ り若干高温側に位置している. NT 処理の WM の ${ }_{V} T_{r s}$ は母材と HAZ より高温側に存在し, 靶性は両者にくら べて格段に低下しているのが特徴的である. NT 処理の HAZ が優秀な切欠勒性を示与のは組織が微細であるた めと思われる。

$\mathrm{SR}$ 処理の場合は, HAZ の遙移が急激であるのに対 して，WM の洎移曲線は緩かになつている。

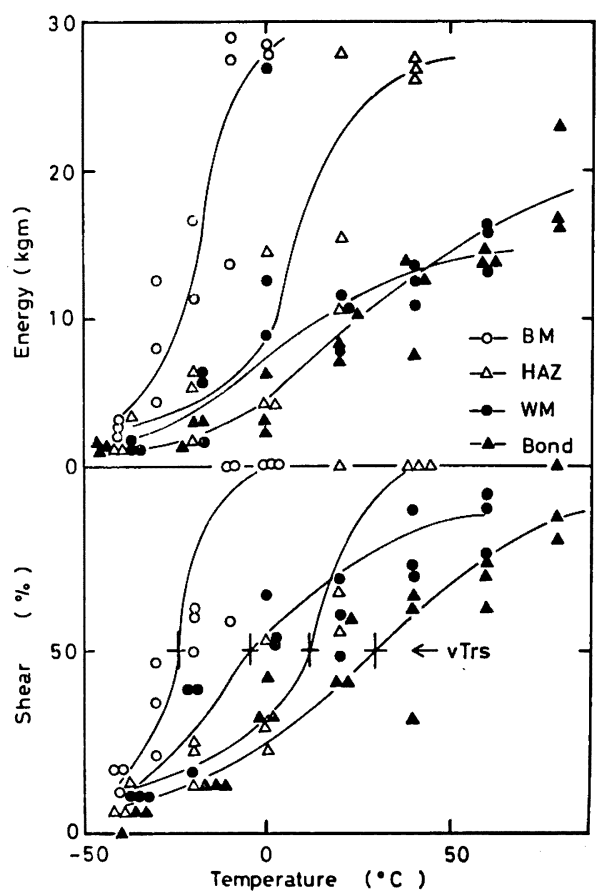

Fig. 2. Charpy transition behaviour of SM41B welded joint under stress relief annealed condition.

Table 4 には各条件下でえられた ${ }_{V} T_{r s}$ と $0^{\circ} \mathrm{C}$ にお ける吸収エネルギー $\left({ }_{V} E_{O}\right)$ の比較を示す. 入熱 $2600 \mathrm{~kJ} /$ $\mathrm{cm}$ の SR 処理溶接部ではボンドの靶性がもつとも劣化 し，WM が良好な特性を示している，また入熱量の大 きい $2800 \mathrm{~kJ} / \mathrm{cm}$ の場合には $\mathrm{HAZ}, W M$ ともに ${ }_{V} T_{r s}$ は高温側に移行し ${ }_{V} E_{O}$ も低下してくる．この靶性の劣 化は組織の粗大化のためと考えられる.

また NTと SR との熱処理の違いをみると，HAZは NT によつて䩖性は格段に向上し，母材とほぼ同等の特 性になつてくる.しかし WM は SR 処理のみの方が靶 性は良好であり，NT することによつて逆に少化するこ とを示した。

\section{3 .4 破壊鞋性値の変化}

板厚 $50 \mathrm{~mm}$ のコンパクトテンション試片 (CT 2)を

Table 4. Charpy impact test results of SM41B electroslag welded joints.

\begin{tabular}{c|c|c|c|c|c}
\hline Heat treatment & Heat-imput & WM & HAZ & Bond & BM \\
\hline SR & 2600 & $-5 / 10.0$ & $12 / 7.0$ & $32 / 4.0$ & $-24 / 28.0$ \\
NT & 2600 & $28 / 3.5$ & $-16 / 29.0$ & - & $-20 / 26.5$ \\
SR & 2800 & $20 / 5.0$ & $33 / 2.5$ & - & - \\
\hline
\end{tabular}

${ }_{\mathrm{v}} T_{\mathrm{rs}},{ }^{\circ} \mathrm{C} / \mathrm{v} E_{\mathrm{fl}}, \mathrm{hg} \cdot \mathrm{m}$ 


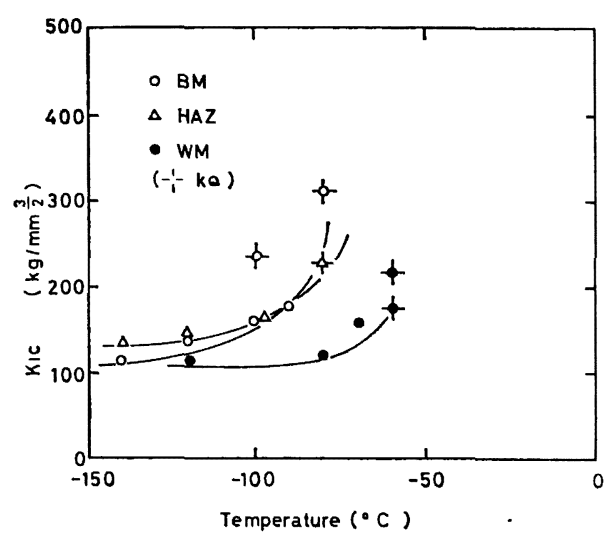

Fig. 3. Temperature dependence of fracture toughness of SM41B welded joints under normalized condition.

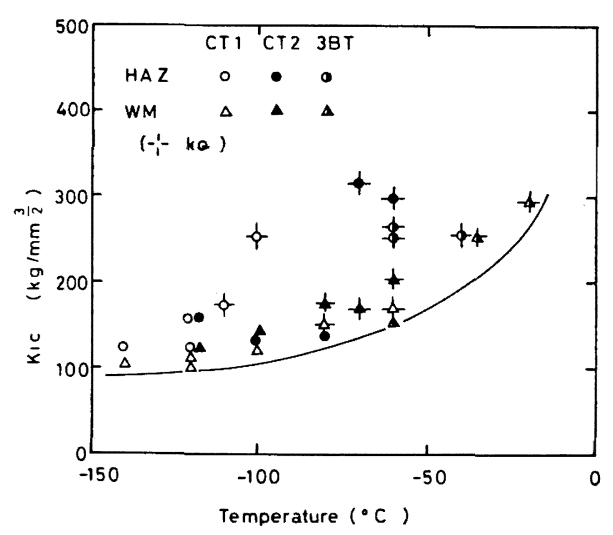

Fig. 4. Temperature dependence of fracture toughness of SM41B welded joints under stress relief annealed condition.

用いて求めた母材および NT 処理溶接部の静的破壊靯 性值 $\left(K_{\mathrm{IC}}\right)$ と温度の関倸を Fig. 3 に示す. valid $K_{\mathrm{IC}}$ は 母材と $\mathrm{HAZ}$ は $-90^{\circ} \mathrm{C}$, WM は $-70^{\circ} \mathrm{C}$ 以下で求ま る.母材と HAZ の $K_{\mathrm{IC}}$ はほぼ同等の値になつている が, $-120^{\circ} \mathrm{C}$ と $-140^{\circ} \mathrm{C}$ では $\mathrm{HAZ}$ の方が若干高い 值を示している. そして各温度で WM の $K_{\mathrm{IC}}$ がもつ とも低い值を示している. この傾向はVシャルピー特性 と一致しており，この差異は前述のミクロ組織の影響に よるものと考えられる.

Fig. 4 には板厚 25 と $50 \mathrm{~mm}$ のコンパクトテンショ ン試片 (CT 1 と CT 2) および板厚 $75 \mathrm{~mm}$ の三点曲げ 試片（3 BT）を用いて行なつた SR 処理溶接部の破壞靶 性試験結果を示す. 当然ながら試片の厚さが小さくなる に従つて valid $K_{\mathrm{IC}}$ の求まる温度は塑性拘束の影響によ
つてより低温側に移行している．またすべての試片とも に NT 処理と同様に SR 処理でも HAZ が WM より 高い値になつている.

同一試片形状で溶接部の $K_{\mathrm{Ic}}$ に及ぼす $\mathrm{NT}$ と SR 処 理の差異をみると次のようになる。

HAZ の $K_{\text {IC }}$ は NT 処理の方が高く,WM では逆に $\mathrm{SR}$ 処理のみの方が高い值になつている.これはVシャ ルピー試験でえられた傾向と同様であり，ミクロ組織の 変化が影響しているためと思われる． $K_{\mathrm{IC}}$ を強度設計基 準として採用する際にはとの下限值を用いるのが通例で ある.これに従えばエレクトロスラグ溶接部では NT 処 理することによつて WM の $K_{\text {IC }}$ が低下してくるので, 後熱処理としては SR 処理のみでよいことになる.

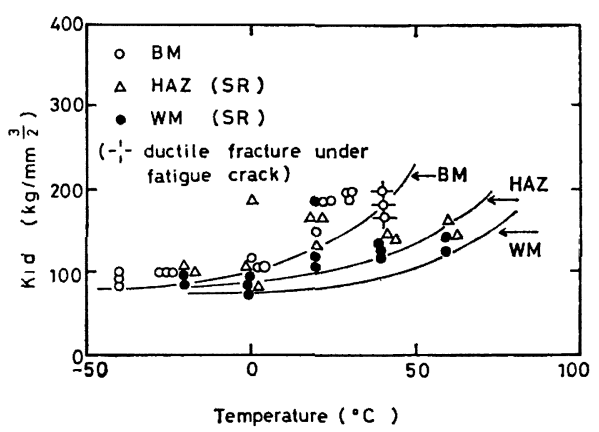

Fig. 5. Temperature dependence of dynamic fracture toughness of SM41B welded joints.

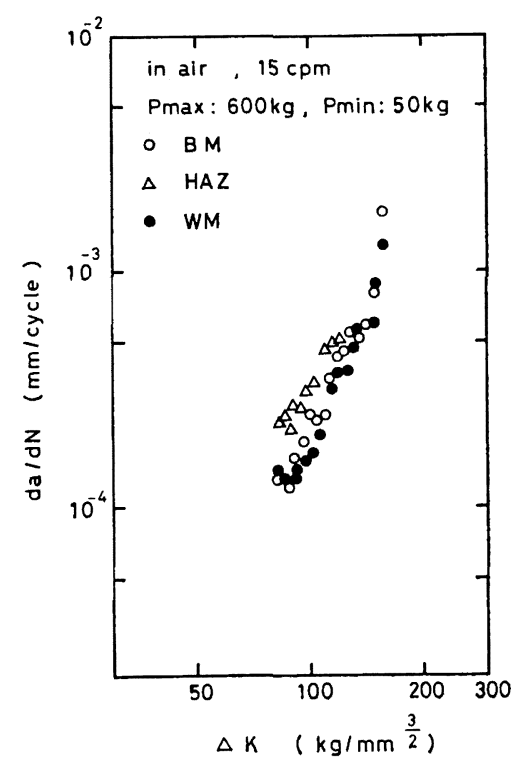

Fig. 6. Fatigue crack growth rate of SM41B welded joints under normalized condition. 
計装化シャルピー試騟㙨を利用して母材と SR 処理溶 接部について求めた動的破壊靶性值 $\left(K_{\mathrm{Id}}\right)$ の温度依存性 を Fig. 5 に示す. それぞれかなりのバラツキを呈して いるが, 約 $0^{\circ} \mathrm{C}$ 以上の温度領域では $\mathrm{WM} \rightarrow \mathrm{HAZ} \rightarrow$ 母

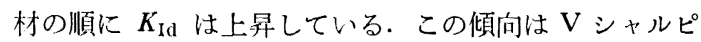
一のシェルフ・エネルギーの変化に一致している. $0^{\circ} \mathrm{C}$ 以下の $K_{\mathrm{Id}}$ は一定値に 収束する傾向を示し, その值は $90 \mathrm{~kg} / \mathrm{mm}^{3 / 2}$ 前後の值になつている.なお， $K_{\mathrm{Id}}$ は巫 速度の影響によつて $K_{\mathrm{IC}}$ より高温側に移行し，かつそ の値は小さくなつている.

\section{5 疲れき裂進展特性}

本実験では疲れき裂進展速度の安定成長領域を下式に 示す Paris 則によつて整理し，結果の検討を行なつた。

$$
d a / d N=C(\Delta K)^{m}
$$

ここで, $d a / d N$ : 疲れき裂進展速度 $(\mathrm{mm} / \mathrm{cycle})$

$\Delta K:$ 応力拡大係数の変動幅 $\left(\mathrm{kg} / \mathrm{mm}^{3 / 2}\right)$

$C$ と $m:$ 材料常数

$15 \mathrm{cpm}$ の繰返し速度においてえられた母材と NT 処 理溶接部の大気中に おける疲れき裂進展特性を Fig. 6 に示す. $\Delta K$ がほぼ $150 \mathrm{~kg} / \mathrm{mm}^{3 / 2}$ 以下では $\mathrm{HAZ}$ がも つとも大きい進展速度になり，WM と母材はほぼ同栐 な特性である. 繰返し速度が $4500 \mathrm{cpm}$ になると母材と WM の相椲はみられず $C$ と $m$ もほぼ同等の值になつ ていた.

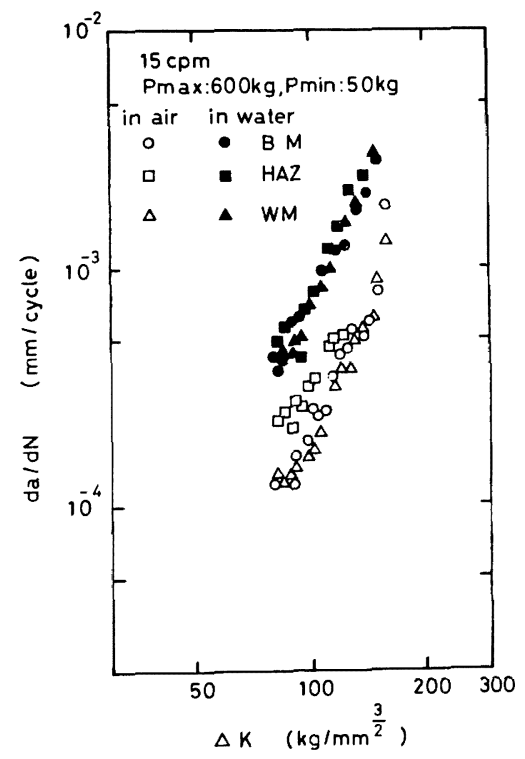

Fig. 7. Comparison of fatigue crack growth rate in air and in water of SM41B welded joints under normalized condition.
また母材と HAZ は同一の $\Delta K$ では繰返し速度の大 きい方が疲れき裂進展速度は低下する傾向があり, 速度 効果が認められる. しかし WM の進展速度は繰返し速 度には依存していなかつた。この相違の理由は明らかで ない，なお，材料常数 $m$ は繰返し速度の大きい方が高い 值になり, 高 $\Delta K$ 籁国では疲れき裂進展速度が加速化 されることを示した。

Fig. 7 には大気中と水中の疲れき裂進展速度の比較を 示す. 水中試駼でえられた材料常数 $C$ と $m$ は大気中と ほぼ同等であるが，同一 $\Delta K$ 領域では大気中よりかな り大きな進展速度になつている。このように腐食環境下 では疲れき裂も急速に進展することを示している。しか しながら水中では母材と溶接部の疲れき裂進展速度に差 異はみられない。

$\mathrm{SR}$ 処理した $\mathrm{HAZ}$ と WM の疲れき裂進展特性を Fig. 8 亿示す. SR 処理溶接部の疲れき裂進展速度は母 材より小さくなり，すぐれた特性を示している.

なお，SR 処理溶接部では繰返し速度の影響は余り認 められず，さらに平均荷重および応力比などが変化して も， $\Delta K$ で整理すると疲れき裂進展速度に差異はみられ なかつた。

本実験でえられた疲れき裂伝播式の材料常数 $C$ と $m$ は NT 処理と SR 処理ではほぼ同等であつたが，同一 の $\Delta K$ でみると HAZ·WN ともに NT 処理の方が大き い進展速度になつている。この詳䋖な要因は明らかでな

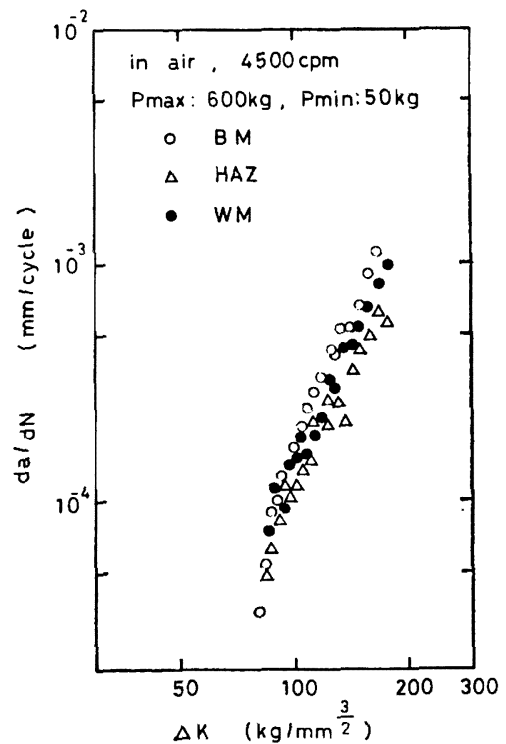

Fig. 8. Fatigue crack growth rate of SM41B welded joints under stress relief annealed condition. 
いが，組織的な影響によるものではないかと思われる。

一方, 北川らわによつて疲れき裂伝播式の材料常数 $C$ と $m$ の間には次式が成立するとされている.

$$
C=B / A^{m}
$$

ここで, $A$ と $B$ は定数である.

母材と NT 処理および SR 処理の溶接部でえられた $C$ と $m$ も線形関係になるが，大気中と水中ではそれでれ別 々の直線で表示され，そのときの関係は次のようになつ t.

$$
\begin{array}{ll}
\text { 大気中 } & C=3.5 \times 10^{-4} / 119^{m} . \\
\text { 水中 } & C=8.3 \times 10^{-4} / 107^{m} .
\end{array}
$$

疲労破面には繰返し応力のサイクルにほぼ対応する条 痕模槉，いわゆるストライエーションが形成される.こ のストライエーションを破面解析によつて定量的に観察 すれ壮㽺労破壊の発生と伝播機構の解明，さらには破壊 事故原因の推察に有効な情報となるといわれている.
In

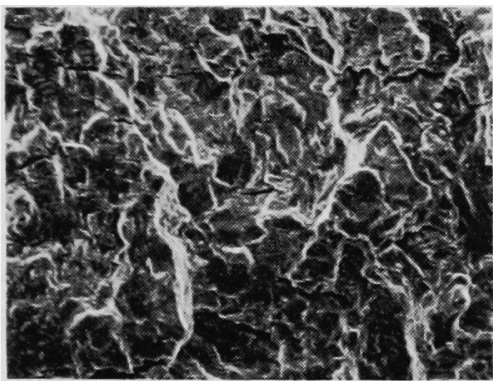

In

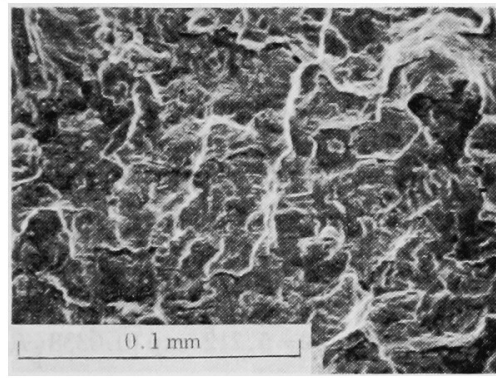

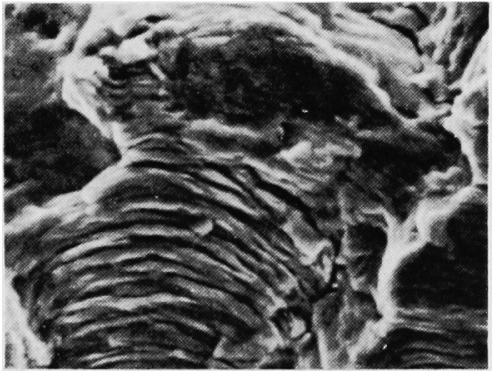

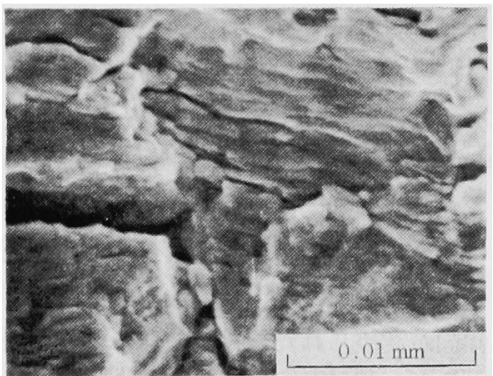

Photo. 2. SEM fractographs of fatigue fracture surface for SM41B steel plate. $\left(\Delta K=115 \mathrm{~kg} / \mathrm{mm}^{3 / 2}\right)$
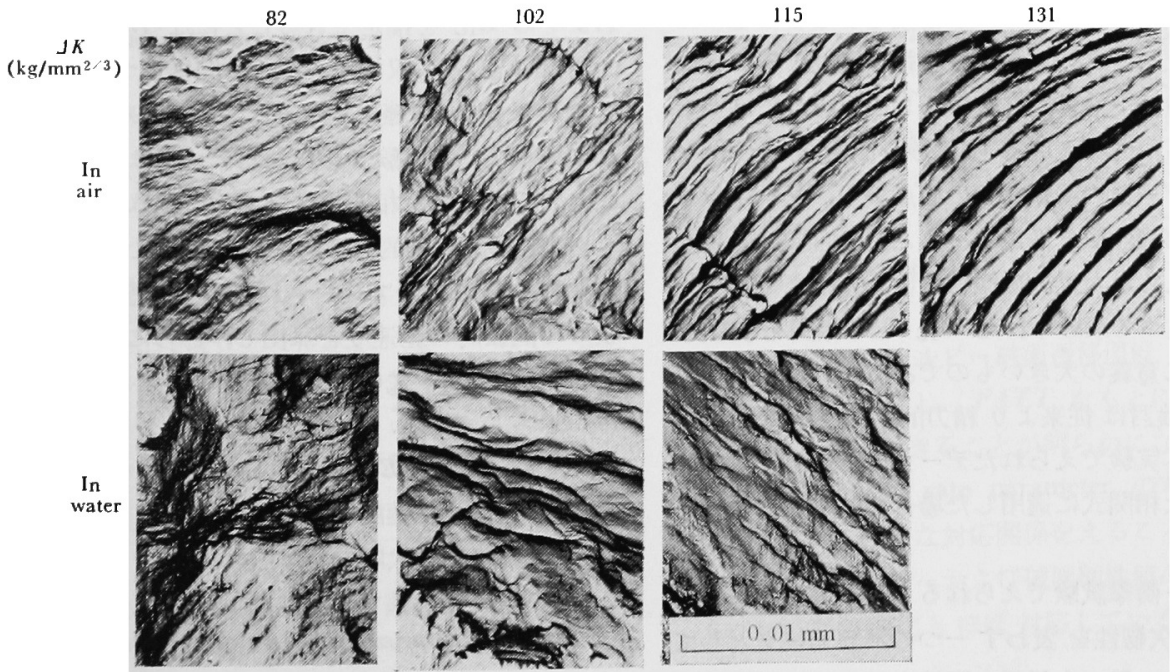

Photo. 3. TEM fractographs of fatigue fracture surface for SM41B steel plate. 
ここでは疲れき裂進展試験を終了した試片の破面を走 查形電子顕微鏡 $(\mathrm{SEM})$ と透過形電子顕微鏡 (TEM, レ プリカ法）で観察した. 走査形電顕による大気中と水中 試片の破面写真を Photo. 2 に示す. 大気中試片ではス トライエーションの生成が観察され, 母材と溶接部によ る破面模様の変化は認められなかつた. 水中試片はスト ライエーションと粒界割れが混在した破面状態を呈して いる. 水中の際にはまず粒界が選択的に腐食され，これ が切欠効果となつてき裂が進行するため擬脆性破面を示 すものと思われる.

レプリカ法で観察した母材の大気中と水中における破 面写真を Photo. 3 に示す. レプリカ法によつて钼察し た場合には，走査形電顕よりもストライエーションを明 確に識別することが可能であり, ストライエーション間 隔をより定量的に測定できることを示している.

大気中の破面には, 全領域にわたつてストライエーシ ョンが観察され，その間隔は $\Delta K$ の増加に従つて拡大 してくる，一方，水中の破面には腐食生成物ならびに腐 食ピットがかなり多く存在しているため, 大気中でみら れたような明瞭なストライエーション模様は観察できな い.しかし部分的にはストライエーションが生成してお り，その間隔は $\Delta K$ の増加とともに拡大しているのが 認められる。またマク口的にえられた疲れき裂進展速度 とストライエーション間隔の関係をみると， $\Delta K$ の低い 範囲では後者の方が大きく, $J K$ が増加するに従つて両 者は一致する傾向が認められた，溶接部も母材と同様な 挙動であつた。

\section{6 破壊靶性値の相関}

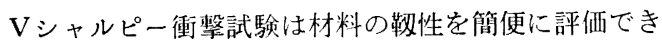
るため幅広く利用され，データの蓄積もかなりのものに なつている．ただ，そのえられる情報は温度との依存性 のみであり，設計上定量的な数值として取扱うには不十 分なものである.しかしながら試験の簡便性・経済性な らびに豊富なデータの蓄積などの観点から，Vシャルピ 一特性から破壊鞋性值を推定すること, さらには計装化 シャルピーでえられた動的破壊鞋性值 $\left(K_{\mathrm{Id}}\right)$ とASTM. E399 などに従つて求められた $K_{\mathrm{IC}}$ との相関を見出す ことは工学的に意義の大きいものである.

この方面の検討は従来より精力的になされてきてい る.ここでは本実験でえられたデータを，従来提案され ている代表的な相関式に嗔用した場合の結果について述 ベる.

Vシャルピー衒揧試験でえられる $50 \%$ 破面遷侈温度 (FATT) は切欠䩖性を表わす一つのパラメータとして 多用されている。， $K_{\mathrm{IC}}$ も材料の政性を示す尺度であるの

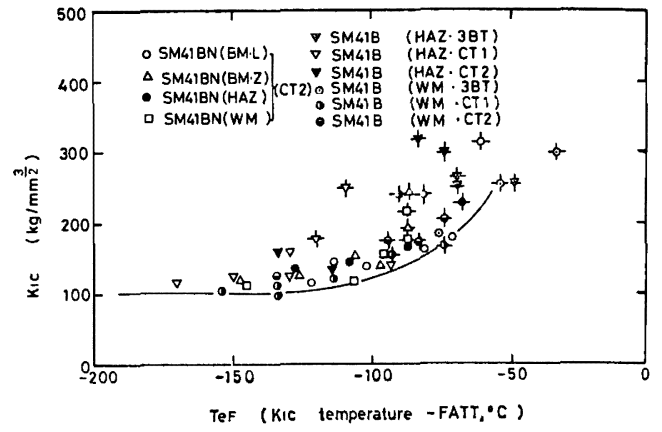

Fig. 9. Summary of fracture toughness $K_{\mathrm{IC}}$ as a function of excess temperature $T_{e F}$.

で，両者の間には相関関係が存在すると予想される。そ していわゆる温度シフト量 $\cdot T_{e F}\left(T_{e F}=K_{\mathrm{IC}}\right.$ 測定温度一 $F A T T)$ で整理することによつて，それぞれの使用温度 における $K_{\mathrm{IC}}$ を推定できることが明らかにされてきて (る8).

Fig. 9 に $K_{\mathrm{IC}}$ と $T_{e F}$ との関係を示す.（図中には著者 らが彷来求めた SM41BN 厚鋼板の板厚方向試験片のデ 一タもプロットした. また図中の SM41BN はNT 処理, SM41B は SR 処理を示す.) この方法で整理すると $K_{\mathrm{IC}}$ と温度との単純な関係よりも $K_{\mathrm{IC}}$ の分散度合が小さく なり，この関係の有效性が示唆される. Fig. 9 の下限線 は次式で示される.

$$
K_{\mathrm{IC}}-100=5.212 \cdot \exp \left\{0.0338\left(T_{e F}+140\right)\right\} \cdots(5)
$$

このときの相関係数は 0.956 ，標準偏差は 0.382 とな る.つまり SM41B とそのエレクトロスラグ溶接部では $F A T T$ が既知であれば，上式より使用温度におけるお およその $K_{\text {IC }}$ を推定できることになる.

また $K_{\mathrm{IC}}$ と吸収エネルギーの関係については ROLFE 9)および田中·伊藤ら ${ }^{10)}$ によつて種々の経験式が提案さ れているが，本実験でえられたデータはこれらの経験式 によつては良好な相関を確立することはできなかつた。

一方，静的と動的破壊靶性值の相関については SHOEMAKERら ${ }^{11)}$ によつて検討されている. 彼らは（6) 式に よつて試験時の歪速度を算出し, さらに歪速度と温度と の相乘積を（７）式のように表わし，これを rate parameterとしている.

$$
\dot{\varepsilon}=2 \sigma_{y} /(t \cdot E)
$$

ここで， $\dot{\varepsilon}:$ 歪速度 $\left(\mathrm{sec}^{-1}\right)$

$$
\begin{aligned}
\sigma_{y} & : \text { 降伏応力 }\left(\mathrm{kg} / \mathrm{mm}^{2}\right) \\
t & : \text { 破壊までの時間 }(\mathrm{sec}) \\
E & : \text { ヤング濏 }\left(\mathrm{kg} / \mathrm{mm}^{2}\right)
\end{aligned}
$$

rate parameter $=T \ln (A / \dot{\varepsilon})$ 


\section{ここで, $T:$ 試験温度 $(\mathrm{K})$}

$\dot{\varepsilon}:$ 阷速度 $\left(\mathrm{sec}^{-1}\right)$

$A:$ 定数 (108 が一般的に探朋されている)

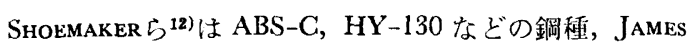
ら ${ }^{13)}$ は ASTM·A 516 鋼の静的と動的破壊䩲性值をこの rate parameter で整理して良好な対応関係をえている.

本実験でえられた $K_{\mathrm{IC}}$ と $K_{\mathrm{Id}}$ の関係を rate parameter で整理した結果の例を Fig. 10 に示す. 同戝よ り明らかなように $K_{\mathrm{IC}}$ と $K_{\mathrm{Id}}$ は良好な闒係になり一本 の線で示される．以上のように SM41B においては，破 壊時の歪速度を考虑することによつて $K_{\mathrm{IC}}$ と $K_{\mathrm{Id}}$ の相 関を確立できることが明らかである。これは SM41Bの 強度が歪速度依存性を有していることと密接に関連して いると思われる。

また $K_{\mathrm{IC}}$ および $K_{\mathrm{Id}}$ の対数を縦軸にとり，横軸には rate parameter の逆数をとると Fig. 11 のようになる. 両者の関係は rate parameter の逆数が $2.6 \times 10^{-4} \mathrm{~K}^{-1}$ 以下で線形関倸が成立しており，この関係を最小二乘法 によつて求めると次式のようになる.

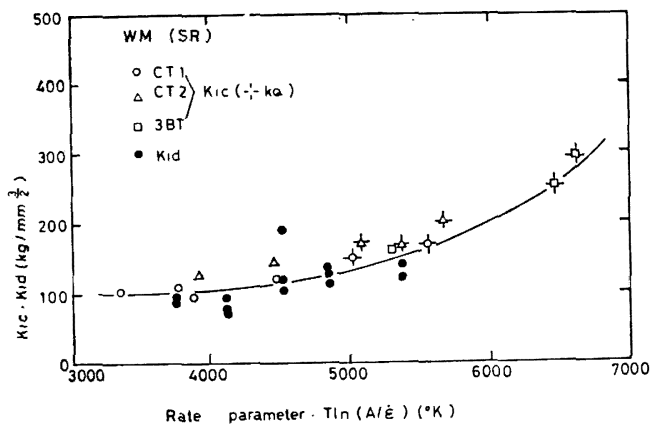

Fig. 10. Correlation between fracture toughness and rate parameter.

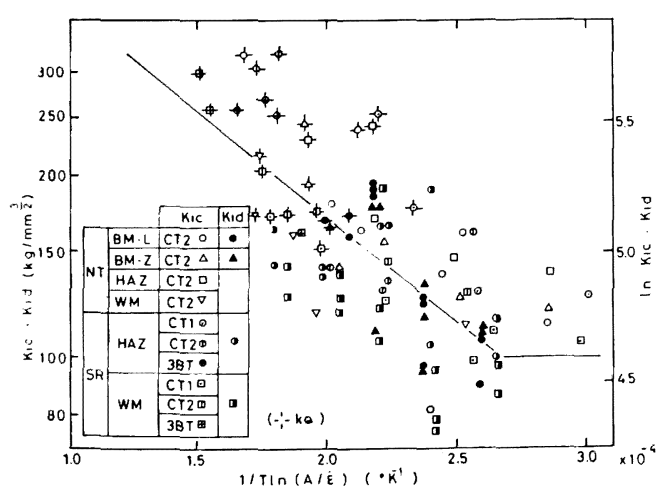

Fig. 11. Correlation between fracture toughness and reciprocal rate parameter.

$$
K_{\mathrm{IC}}\left(K_{\mathrm{Id}}\right)=856 \cdot \exp \left[-\frac{0.804 \times 10^{4}}{T \ln (A / \dot{\varepsilon})}\right] \cdots
$$

この式における標準偏差は 0.290, 標準誤差は 0.237 , そして相閔係数は -0.704 になつている.

破壊時における疋速度と温度がわかれば上式によつて 破壊鞁性值（ $K_{\mathrm{IC}}$ および $K_{\mathrm{Id}}$ ) を算出できる.また小形 試験片で評㑛可能な $K_{\text {Id }}$ において上式を確立しておけ ば，大形試験片で求められる $K_{\mathrm{IC}}$ を推定することが可 能となる・

以上のように，ある範囲においては $K_{\mathrm{Id}}$ より $K_{\mathrm{IC}}$ を 推定できることが明らかである.

\section{4. 結言}

発電朋水車構造部材に使用される板厚 $110 \mathrm{~mm}$ の SM $41 \mathrm{~B}$ 厚鋼板エレクトロスラグ溶接部の械機的性質, 切欠 靶性および破壊鞋性值と疲れき裂進展速度等に及ぼす溶 接条件 (入熱量)および後熱処理の影響について実験を 行なつた。また, 疲労破面の解析さらには静的と動的破 壞靶性值との相関などについても検討を実施した。

本実験でえられた主な結果は次のように要約される。

1) 溶接部の引張特性は NR 処理すると $\mathrm{SR}$ 処理よ り強度は低下するが，延性は向上する. また溶接部と母 材の引張特性には大きな差異はみられなかつた。

2） Vシャルピーで評仙される切欠䩒性は NT 処理 では溶接金属（WM）がもつとも劣化し，HAZ は母材 とほぼ同等の特性になる. SR 処理では HAZより WM の鞁性が良好になつた。

3) 静的破壞靶性值 $\left(K_{\mathrm{IC}}\right)$ は NT 処理および SR 処 理ともに HAZ が WM より高い值になり，䩲性のすぐ れていることを示した. NT 処理した HAZ の $K_{\mathrm{IC}}$ は 母材とほぼ同等であつた． $K_{\mathrm{IC}}$ を強度設計基準として採 用する際にはその下限值を用いるのが通例である。これ に従えばエレクトロスラグ溶接部は NT 処理すること によつて WM の $K_{\mathrm{IC}}$ が低下してくるので後熱処理と してはSR 処理のみでよいと判断された。

4) 計装化シャルピーで評洒した動的破壞靶性值 $\left(K_{\mathrm{Id}}\right)$ は $K_{\mathrm{IC}}$ と同様に $\mathrm{WM} \rightarrow \mathrm{HAZ} \rightarrow$ 母材の順に上昇 した.

5) $K_{\mathrm{IC}}$ とシャルピー破面遷移温度 $(F A T T)$ の間に は相関関係が成立し，FATT をもとに使用温度に打け る $K_{\mathrm{IC}}$ を推定できることが明らかになつた・また $K_{\mathrm{IC}}$ と $K_{\mathrm{Id}}$ の関係は rate parameter の考え方を導入する ことによつて良好な対応関係をえることができた。

6) Vシャルピーおよび破壊靶性值の差異は主として ミクロ組織の変化とほぼ対応していることが認められ 
た。

7）疲れき裂進展速度は母材打よび NT 処理溶接部 より SR 処理の方が小さくなる傾向を示した。また NT 処理では HAZ の速度が大きくなつているが, SR 処理 の HAZ と WM はほぼ同等の特性を示した：水中の 疲れき裂進展速度は大気中より大きくなるが，母材と溶 接部との差異は夕られなかつた．さらに疲れき裂伝播式 の材料常数 $C$ と $m$ の間には線形関係が成立した.

終りに，本諭交の発表を許可された富士電機製造(株) 中央研究所・島崎昭夫所長ならびに本実駼に用いた溶接 継手の製作を担当していただいた品質管理部・構造実験 室と川崎工場・製造部の各位に対し深く感謝致します。 また本実験の遂行に当つて終始熱心に協力された中央研 究所・第二部の沢田寿夫氏，山下满男氏就よび大井婦知 恵袞に謝意を表します。

\section{交献}

1) 例えば，金沢正午，山戸一成，井上尚志，橋本勝 邦: 溶接学会誌，45 (1976) 2, p. 128 など

2 ）船越督己，田中智夫，上田修三，石川正明，腰场 典明，小林邦彦：鉄と鋼，63 (1977) 2, p. 303
3 ）松本浩造, 沢田寿夫, 森田益夫: 日本材料強度学 会讙演論交集，(1977)，p. 5

4 ) 山下满男, 松本浩造, 近荻柴作: 日本材料強度学 会諯演論文集，(1977)，p. 67

5 ) 小串泰三, 浜田和則, 松本浩造, 高井耕一, 森田 益夫，松村磨一：溶接学会全国大会鿁演概要，第 21 集 (1977), p. 162

6 ）小串泰三, 捠田和則, 松本浩造, 高井耕一, 森田 益夫，松村慶一：溶接学会全国大会洲演概姴，第 21 集 (1977)，p. 164

7 ) 北川英夫, 三角正明: 日本機械学会講演論交集, No. 714-10 (1971), p. 67

8) H. D. Greenburg: Paper on 5th International Forgemasters Meeting, (1970) Terni

9 ) J.M. BARsom and $S$. T. Rolfe: ASTM STP, $446(1970)$

10）伊藤悌二, 田中 潔, 佐藤 誠: 日本造船学会論 文集, 第 131 号 (1972)

11) $H . T$. Corten and $A . K$. Shozmaker: Trans. ASME, 89 (1967), p. 86

12) $A . K$. Shomaker and $S . T$. Rolfe: Trans. ASME, 91 (1969), p. 512

13) Lee A. JAmes: Weld J., 51 (1972), $506 \mathrm{~S} \sim 507 \mathrm{~S}$ 